\title{
Nutraceutical and Probiotic Approaches to Examine Molecular Interactions of the Amyloid Precursor Protein APP in Drosophila Models of Alzheimer's Disease
}

\author{
David Jalali ${ }^{1}$, Justine Anne Guevarra ${ }^{2}$, Luz Martinez ${ }^{1}$, Lily Hung ${ }^{1}$ and Fernando J Vonhoff $1, * \mathbb{C}$ \\ 1 Department of Biological Sciences, University of Maryland Baltimore County, Baltimore, MD 21250, USA; \\ ejal1@umbc.edu (D.J.); luzmar1@umbc.edu (L.M.); lilyh1@umbc.edu (L.H.) \\ 2 Department of Biological Sciences, Towson University, Towson, MD 21252, USA; \\ jgueva2@students.towson.edu \\ * Correspondence: fvonhoff@umbc.edu
}

check for updates

Citation: Jalali, D.; Guevarra, J.A.; Martinez, L.; Hung, L.; Vonhoff, F.J. Nutraceutical and Probiotic Approaches to Examine Molecular Interactions of the Amyloid Precursor Protein APP in Drosophila Models of Alzheimer's Disease. Int. J. Mol. Sci. 2021, 22, 7022. https://doi.org/ $10.3390 /$ ijms 22137022

Academic Editors: Serge Birman, Frank Hirth and Emi Nagoshi

Received: 24 May 2021

Accepted: 24 June 2021

Published: 29 June 2021

Publisher's Note: MDPI stays neutral with regard to jurisdictional claims in published maps and institutional affiliations.

Copyright: (c) 2021 by the authors. Licensee MDPI, Basel, Switzerland. This article is an open access article distributed under the terms and conditions of the Creative Commons Attribution (CC BY) license (https:/ / creativecommons.org/licenses/by/ $4.0 /)$.

\begin{abstract}
Studies using animal models have shed light into the molecular and cellular basis for the neuropathology observed in patients with Alzheimer's disease (AD). In particular, the role of the amyloid precursor protein (APP) plays a crucial role in the formation of senile plaques and aging-dependent degeneration. Here, we focus our review on recent findings using the Drosophila AD model to expand our understanding of APP molecular function and interactions, including insights gained from the fly homolog APP-like (APPL). Finally, as there is still no cure for AD, we review some approaches that have shown promising results in ameliorating AD-associated phenotypes, with special attention on the use of nutraceuticals and their molecular effects, as well as interactions with the gut microbiome. Overall, the phenomena described here are of fundamental significance for understanding network development and degeneration. Given the highly conserved nature of fundamental signaling pathways, the insight gained from animal models such as Drosophila melanogaster will likely advance the understanding of the mammalian brain, and thus be relevant to human health.
\end{abstract}

Keywords: nutrition; neurodegeneration; gut microbiome; insect disease models

\section{Introduction}

Alzheimer's disease (AD) is one of the most well-known and widespread neurodegenerative diseases worldwide [1,2]. It is estimated that around 50 million people live with dementia and that $60-70 \%$ of these people live with $\mathrm{AD}$, with a projected increase to 152 million by 2050 [3,4]. Thus, it is of paramount importance to explore novel avenues of research which may help in treating the disease, slowing its progress, and potentially even preventing its onset altogether. Although there is still no cure for Alzheimer's disease, it is worth highlighting some novel treatments that would require further testing based on promising initial results. We will mostly discuss nutraceutical compounds (naturally occurring chemicals in food that may have medicinal benefits) as well as synbiotic formulations and their interactions with the gut microbiome tested in Drosophila that have the potential to alleviate AD-related symptoms. In addition, we will highlight recent studies using Drosophila AD models that have expanded our understanding of the molecular mechanisms underlying AD-associated phenotypes, with a specific focus on the amyloid precursor protein (APP) and its fly homolog APP-like (APPL).

\section{AD Symptoms, Progression and Diagnosis of Neuropathology}

Key symptoms of AD mainly involve declining levels of cognition, specifically through loss of short and long-term memory [5]. In addition, patients can develop problems with their speech, spatial orientation and memory, and decreased stability in their emotional 
state. As the disease mainly affects elderly people, there is also a high risk for other underlying health conditions to be neglected or affected adversely by this disease [1], ultimately increasing their risk of injury or death. In addition, due to the neurodegenerative nature of the disease, steady progression can lead to complications in overall brain functionality. As a result, the typical life expectancy for most patients ranges between 3 and 9 years after their initial diagnosis [6].

As discussed in the next section, $\mathrm{AD}$ neuropathology involves the buildup of neuritic plaques of amyloid- $\beta$ (A $\beta$ ) aggregates outside of neurons [7], neurofibrillary tangles of hyperphosphorylated tau, a microtubule-associated protein, within the affected neurons [8] and neuronal loss $[9,10]$. Therefore, $\mathrm{AD}$ pathology and progression have been analyzed by classic postmortem studies, as for example, the Braak staging [11-13]. However, recent efforts have focused on developing alternative methods to examine AD neuropathology with the goal to identify initial AD signs antemortem, as for example, using positronemission tomography (PET) scans for tau and $A \beta$ imaging as discussed below, to indicate that the presence of sufficient quantities of both would permit a diagnosis of AD.

Based on the progression of mental and intellectual decline, AD is classified into three stages: "Early", "Middle" and "Late", as described by the Alzheimer's Association (www.alz.org, accessed on 24 May 2021). These stages are considered rough generalizations and can be further subdivided into five (www.mayoclinic.org, accessed on 24 May 2021) or even seven stages (www.pennmedicine.org, accessed on 24 May 2021). The first signs can be mistaken for old age, leading to a delayed diagnosis [1]. "Early Stage" hallmarks include difficulty learning new facts or forming new memories, reduction in vocabulary, and some minor difficulties with fine motor tasks [14]. Memories from earlier life and implicit memory, such as how to drink from a glass, are typically not affected at this stage [15].

The "Middle Stage" is when patients often begin to lose their ability to live independently [16]. Vocabulary loss increases dramatically, and motor skills and coordination decrease significantly, leading to much-increased risks of falling and subsequent injury [17]. Long-term memory also becomes impacted, which can lead to the patient having a hard time recognizing close family members [17]. This stage is also characterized by psychosis and erratic behavior, as well as a loss of control of bodily functions such as urination [16]. Due to the nature of these symptoms, patients often begin requiring consistent care and monitoring, and many of them move to assisted-living facilities as a result [18].

The final stage, known as the "Late Stage", is used to classify patients with the most severe symptoms. Due to the harshness of their symptoms, patients in this stage often lose all independence in their day-to-day lives, requiring around-the-clock monitoring and help, even with the most basic activities [19]. Speech and language skills are almost completely lost, and due to decreased mobility, there is significant muscular atrophy, which ultimately leads patients to be confined to their beds [16]. Due to this bedridden state, one of the most common causes of death for Alzheimer's patients is the infection of pressure ulcers [20].

Although the cognitive tests described above can help with AD diagnosis in terms of probability, growing efforts have focused on elucidating what is called the "preclinical stage" [21]. Identification of an individual in the asymptomatic preclinical state is accomplished by the in vivo evidence of AD-pathology, which includes the existence of anatomical and molecular AD biomarkers [22,23]. The identification of anatomical and molecular markers via structural and molecular imaging represents a promising method to examine the neuropathology of AD antemortem as proposed by the Alzheimer's Prevention Initiative (API) [24,25]. Studies on AD biomarkers such as cerebrospinal fluid A $\beta 42$ and tau have indicated a long preclinical phase of the disease of several decades before symptom onset $[1,26,27]$. Another characteristic of AD progression includes the gradual degeneration of neurons in the cerebral cortex, temporal and parietal lobes [28]. As a result, one of the recently utilized methods to diagnose early disease stages involves magnetic resonance imaging (MRI) to measure regional or whole-brain shrinkage between patients and healthy adults [29]. There is also an assortment of radiopharmaceutical agents used 
specifically with PET scans to help with the diagnosis, including Florbetapir, Flutemetamol and Florbetaben as A $\beta$ tracers [30], as well as the first approved PET tau tracer, Flortaucipir (trademark name: Tauvid) [31]. Fluorodeoxyglucose (FDG) PET measurements of decline in the cerebral metabolic rate of glucose (rCMRgl) have been recognized as an estimate of neuronal hypometabolism [32,33]. Hypometabolism has been previously proposed as a therapeutic target in AD [34] as well as an independent biomarker [35], particularly after considering observations from autopsy studies in the 1980s showing impairments in brain glucose utilization and energy metabolism [36-39]. Additionally, other techniques such as blood testing can be used to rule out other causes of cognitive impairment, such as syphilis or heavy metal poisoning.

Different methods have been used to model AD and examine its progression, pathology and responses to various treatments. Stem cell-based organoid development and disease modeling have been proposed as promising novel techniques to investigate $\mathrm{AD}$ pathogenesis [40], but several shortcomings and challenges are worth noting. Aging is one of the largest risk factors in AD development, but stem-cell-derived organoids tend to demonstrate transcriptional profiles similar to that of a prenatal brain as well as immature electrical activity patterns, rather than the more complex profiles seen in older individuals [41,42]. Additionally, organoids lack the vascularization observed in brains, and such vascularization is critical in being able to replicate not only the disease, but also the brain anatomy that affects the disease progression [41]. Another challenge is the lack of complexity and diversity of cell types, including reduced numbers of microglia and astrocytes [42]. Finally, there are limitations with regard to the integration of specialized cells such as oligodendrocytes or microglia, or the development of neuronal circuitry that would be of similar complexity to those seen in animal models [41]. Consequently, while the use of stem-cell-derived organoids is an intriguing prospect and there is still much room for improvement, animal models remain a viable approach for replicating the disease pathology, progression and environment.

\section{AD Pathogenesis and Amyloidogenic APP Processing}

The main neuropathological hallmarks of AD brains include senile plaques and neurofibrillary tangles, as well as neuronal and synaptic loss [43]. Plaques are buildups of processed fragments of the amyloid precursor protein (APP), while tangles are intracellular neurofibrillary buildups of tau proteins [44]. Tau proteins are a group of protein isoforms created through alternative splicing of the microtubule-associated protein tau (MAPT) [45]. They are typically involved in maintaining axon stability through interactions with microtubules, but in AD cases, they become hyperphosphorylated and form neurofibrillary tangles [46]. Although evidence suggests that $A \beta$ deposition and tau pathology can precede neuronal and synaptic loss [47-49], especially considering observations from longitudinal imaging of dystrophic neurites and plaques in rodent AD models [50-52], the precise timing of the start of neuronal and synaptic loss in AD patients remains to be accurately determined. Despite both plaques and tangles being the main accepted causes of the disease, a recent consensus has been established showing a synergistic effect between the plaques and tangles, and that elimination of the plaques alone can lead to the amelioration of the disease and its symptoms [44,53]. An important factor to consider is the aging-dependent decline in the clearance of plaques from the extracellular space, leading to the $\mathrm{A} \beta$ plaque buildup and subsequent development of AD symptoms [54]. Therefore, we will focus our discussion of this review on recent advances in understanding APP molecular roles and interactions.

Amyloid- $\beta$ (A $\beta$ ) is a cleavage product of the Amyloid Precursor Protein, APP [55]. APP is an integral membrane protein, and while it is expressed in a wide variety of different cell types [56], it shows particularly high expression levels on neuronal membranes, especially in synapses [57]. A well-known function of APP surrounds its involvement in the formation and repair of synapses [57]. This APP function is especially evident following neural injury, as well as during the differentiation of neurons when the expression level 
of APP is significantly upregulated [58]. Additionally, APP is observed to have a trophic function, promoting cell proliferation, differentiation, neurite outgrowth, cell adhesion and synaptogenesis [59] and to be involved in neural stem cell development, neuronal survival and neurorepair [59,60]. Furthermore, APP is also believed to be highly important in reproductive endocrinology, where differential splicing of the protein is key in regulating the differentiation of embryonic stem cells into neural precursor cells [61].

The APP protein is encoded by the gene of the same name, which is located on chromosome 21, spanning 290 kilobases [62]. APP has many different isoforms, and it ranges from 639 to 770 amino acids in length, being the one with 695 amino acids (APP695) the predominant isoform of APP in mammalian neurons [55,63], with a large portion of the protein residing in the extracellular space. This protein is often subjected to a wide range of post-translational modifications, including phosphorylation, glycosylation and proteolytic cleavage [64]. Of these post-translational modifications, proteolytic cleavage seems to be directly involved in the generation of $A \beta$ plaques [65]. There are two cleavage pathways for APP, and they are known as "Amyloidogenic" and "Non-Amyloidogenic" [66]. In the "Non-Amyloidogenic" pathway, the extracellular domain of the APP protein is cleaved by a protease enzyme known as $\alpha$-secretase. Following the $\alpha$ cleavage, the protein is then cleaved again by $\gamma$-secretase, leading to the generation of a soluble larger fragment and a smaller fragment known as $\mathrm{p} 3$ [66]. This pathway, as the name implies, does not seem to have any pathogenic effects. However, in the "Amyloidogenic" pathway, rather than being cleaved by $\alpha$-secretase, the APP extracellular domain is first cleaved by $\beta$-secretase (also known as BACE-1), and then by $\gamma$-secretase, leading to the generation of another large soluble fragment, but also the $A \beta$ fragment [66]. These $A \beta$ fragments cluster together and become aggregates, forming the aforementioned plaques.

\section{APP Genetic and Molecular Interactions}

Overexpression of the APP gene significantly increases both AD severity and progression rate, particularly observed in individuals with Down Syndrome (Trisomy 21), who have three copies of this gene and demonstrate AD symptoms as early as 40 years of age [67]. Furthermore, Down Syndrome patients demonstrate a similar buildup of plaques, neurofibrillary tangles, inflammation and oxidative stress as seen in AD patients, and this is believed to be due to triplicate expression of APP [68]. This is further supported by the observation of elevated levels of APP mRNA concentrations of APP in the brains of AD patients [69].

To date, a total of 69 mutations in APP have been reported, with32 reported as pathogenic in the Alzforum database (https://www.alzforum.org/mutations/app, accessed on 24 May 2021). One of the most popular APP mutations is known as the "Swedish Mutation", originally discovered in two separate Swedish families who presented significantly elevated levels of $\beta$-amyloid production, along with symptoms characteristic of $\mathrm{AD}[70,71]$. The mutation results in a two amino acid change adjacent to the site of cleavage by BACE- 1 on the APP protein, specifically changing lysine and methionine to asparagine and leucine (p.K670N and p.M671L), respectively [72]. This mutation increases the absolute levels of $A \beta 42$ and the rate of protofibril aggregation (without changing the $A \beta 42$ to $A \beta 40$ ratio) [72]. Due to these results, the "Swedish Mutation" has been a popular target for the generation of Drosophila and mouse models of Alzheimer's disease [73].

While the vast majority of mutations discovered on the APP gene are considered to be generally pathological, one recently discovered mutation is believed to be the first to demonstrate a correlative protective effect. The "Icelandic A673T mutation", as implied by its name, was first found in populations of Iceland and Scandinavia. People heterozygous for this mutation did not have any adverse neurological conditions. On the contrary, they were found to be protected against declines in cognition associated with age [74]. One intriguing report involved a 104-year-old woman heterozygous for the mutation who had little to no amyloid pathology, despite her age and the presence of hippocampal sclerosis [75]. Other reports have demonstrated that individuals with Scandinavian ancestry 
have similar resilience against $A \beta$ plaque formation and the accompanying pathogenic neurodegeneration [76].

Biologically, the A673T mutation is believed to be similar to the pathogenic Swedish mutation, in that it modifies residues in very close proximity to the primary cleavage site targeted by $\beta$-secretase; however, the resulting phenotypes are very different [74]. The " $\mathrm{A}$ " residue is the second residue in the $\beta$-amyloid domain of the APP protein. This alanine to threonine mutation has several effects. First, it is believed that this mutation results in a less-favorable conformation of the protein for $\beta$-secretase to cleave [74]. Second, due to the decreases in cleavage, this mutation also results in reduced $A \beta$ levels [77]. Finally, it is believed that the $A \beta$ fragments which are formed despite the presence of this mutation do not have the same ability to form clusters and show lower $A \beta$ oligomer-binding affinity compared to wild-type $A \beta$, resulting in almost no aggregation or plaque formation [77-79]. Such trends have been observed in mouse and rat models of the A673T mutation, as well as isogenic human-induced pluripotent stem-cell-derived neurons, with the mutation being correlated with decreased amyloidogenic processing of APP, as well as reduction of A $\beta$ aggregation $[77,80]$.

APP is an evolutionarily conserved protein, and it is expressed in many different organisms, including Drosophila and mice [81,82]. However, it is absent in animals that lack muscles and a nervous system, such as Trichoplax adhaerens $[83,84]$. Although animal nervous systems may lack some complexity and high cognitive functions present in human brains and findings in animal modes may not always translate into efficacious treatments for human patients, the high degree of conservation of fundamental processes animal models supports their use to unravel mechanisms underlying distinct abnormalities and pathophysiological development as well as to develop effective treatment strategies [85]. For example, many models of neurodegenerative diseases have been developed using Drosophila, including those for Parkinson's disease, amyotrophic lateral sclerosis (ALS), Huntington's disease, Rett syndrome, ataxia telangiectasia and Alzheimer's disease [86-88]. We will focus our discussion on some recent findings from Drosophila studies in the section below and highlight some of the novel nutraceutical and synbiotic approaches that have demonstrated promising results in ameliorating APP-dependent phenotypes.

\section{Recent Research on APP: Insights from Drosophila}

Drosophila expresses the "APP-like" (APPL) protein, which has high homology with human APP (hAPP) in both the N-terminal extracellular domains, as well as the C-terminal intracellular domain [89-91]. It is important to note that there are different views about the conservation degree of the domain encoding the $A \beta$ region between both proteins. Whereas some groups indicate that it is not present in Drosophila APPL [90,92], other labs have shown that the secreted A $\beta$-like peptide resulting from APPL cleavage is conserved to hAPP $[93,94]$. Interestingly, hAPP expression rescues some of the phenotypes observed in appl null flies [95], suggesting that functionally, the two proteins are very similar. Conserved motifs between hAPP and Drosophila APPL have also been shown to serve the same physiological roles, and that they are sufficient and interchangeable for proper neural functionality [58].

Overexpression of wild-type and mutated hAPP has been the strategy of established Drosophila AD models for several years (reviewed in $[96,97]$. Recent studies showed that APP overexpression in flies disrupted sleep patterns, one of the earliest symptoms observed in AD patients [98]. Interestingly, middle-aged flies expressing hAPP demonstrated significant disruption in their sleep patterns, with decreases in daytime and total sleep amounts. This effect was exaggerated in older flies, which revealed consistently increased numbers of sleep bouts and disruption, decreased overall sleep amounts and significant sleep fragmentation [98]. In fact, sleep disorders appear at early AD stages and rise with the severity and progression of $\mathrm{AD}$ [99], but the direct mechanisms behind this finding require further investigation. One hypothesis is that regular sleep-wake cycles cause a fluctuation in the amount of $\mathrm{A} \beta$ deposition, whereas the development of unclearable plaques disrupts 
this fluctuation [100]. This results in a positive feedback loop, where reduced sleep leads to reduced $A \beta$ clearance, leading to a further reduction of sleep and a further buildup of plaques [100]. Therefore, powerful genetic tools and a large body of literature on sleep and sleep disorders [101-103] make Drosophila a promising model to further investigate the relationship between sleep, APP and human disorders.

A recent study in Drosophila demonstrated disruption of autophagy following the altered expression of the activating subunit of the Cdk5 protein kinase (Cdk5 $\alpha$ ) [104]. Such disruption of autophagy caused the hyperactivation of innate immunity, which in turn induced the age-dependent death of dopaminergic neurons, establishing a fly model to study autophagy, innate immunity and neurodegeneration $[104,105]$. The autophagic pathway and innate immunity have been involved in neurodegenerative diseases, including $\mathrm{AD}$ [106]. In the context of $\mathrm{AD}$, previous research has not clarified whether this dysregulation is a cause or effect of the pathological state. Research by Zhuang and colleagues demonstrated that the aberrant autophagy seen in Drosophila AD models is due to abnormally elevated levels of APP, which leads to a positive feedback loop of dysregulation in APP metabolism and further worsened symptoms. The protein chaperone E3 ligase known as CHIP (carboxyl-terminus of Hsc70-interacting protein), which is a key component in the autophagic pathway, induces $\mathrm{A} \beta$ production by increasing the expression of BACE- 1 , leading to aberrant autophagy and subsequent neurodegeneration [107]. A suppression of APP-induced neurodegenerative effects in eye development was observed by downregulating CHIP activity [107]. Additional APP-induced deficits in wing expansion, locomotion and an overall reduction in lifespan were all ameliorated by the depletion of the CHIP chaperone E3 ligase [107]. Human CHIP shares 60\% amino acid sequence similarity with fly CHIP [108], and is involved in high metabolic activity and protein turnover, but no role of CHIP in APP regulation and AD pathogenesis was known.

Another Drosophila study examined the role of APP in memory formation and memory loss, as one of the keystone symptoms of $\mathrm{AD}$ is a loss of both short and long-term memory. Using RNA interference, interactions between the intracellular domains of APPL and membrane-associated guanylate kinase proteins (MAGUK) were shown to be critical for appetitive long-term memory, memory which is needed for intrinsic survival functions such as eating and drinking [109]. Additionally, their genetic analysis suggested that these interactions would not only be present in Drosophila, but may be conserved across many different species, including humans [109]. Consistently, deficits in learning and memory have been previously reported not only in appl null flies [110,111], but also in global APP knockout mice [112]. In fact, some neurons in the learning and memory center of the fly brain, the mushroom bodies, presented modestly penetrant axonal defects in appl null flies [113], a process that is thought to involve interactions between APPL, the Wnt-PCP signaling pathway, the tyrosine kinase $\mathrm{Abl}$ and the fly huntingtin protein $\mathrm{Htt}$ [114]. Additional phenotypes recently described in appl null flies include a significant compromise in survival at early ages, neuronal cell death, enlargement of early endosomal compartments and the accumulation of dead neurons in their brains [115]. Consistently, global APP knockout mice have also demonstrated significant impairments in cerebral blood flow, especially when exposed to hypoxic conditions, ultimately causing acute mortality [116].

\section{The Use of Nutraceuticals as Promising Treatment Options}

$\gamma$-secretase was the target of one of the first drugs (Semagacestat) meant to treat AD. It unfortunately had very dire consequences and was canceled during phase 3 clinical trials over safety concerns (e.g., patients treated with Semagacestat had a significantly higher incidence of skin cancer than those who were given a placebo) and worsening of the pathological conditions [117]. Whether these results were due to the targeting $\gamma$ secretase has never been determined and lends support to the need to understand the basic biology of these proteins. Similarly, since BACE-1 is a unique component of the Amyloidogenic pathway, there have been quite a few BACE-1 inhibitor drugs undergoing 
clinical trials [65]. However, adverse effects have been observed in many drug trials targeting BACE-1. For instance, "Verbucestat", a novel BACE-1 inhibitor from Merck, was shown to cause increases in falls and injuries, suicidal thoughts, sleep disturbance and other undesirable side effects [118]. Janssen also suspended their BACE-1 inhibitor "Atabecestat" during their phase 2 clinical trials due to liver toxicity [119]. Other attempts at inhibiting BACE-1 have brought about impairment of synaptic transmission, plasticity and longterm hippocampal potentiation, which ultimately bring into question whether or not this therapeutic treatment will be effective and non-invasive [65]. A comprehensive description of some of the drugs described above, as well as additional promising therapeutic and synthetic agents, has been recently reviewed [120-122].

A more promising approach to reduce BACE- 1 activity has been recently shown in Drosophila AD models, which involves a nutraceutical treatment with gallic acid [123]. Gallic acid is a trihydroxybenzoic acid found in a wide variety of plants, ranging from sumac to tea leaves, oak trees and blue-green algae. It is classified as a phenolic acid with strong antioxidant and free radical scavenging properties. It is also found in many edible fruits, such as strawberries, bananas and grapes. AD-flies exposed to different concentrations of gallic acid in their diet (50 and $100 \mu \mathrm{M})$ showed reduced activity of cholinesterases and $\beta$-secretase (BACE-1) as well as concentrations of reactive oxygen species and malondialdehyde [123]. The therapeutic potential of gallic acid is exciting, as elevated BACE-1 activity is often seen in severe AD cases and leads to increases in A $\beta$ production. While previous efforts to inhibit BACE-1 demonstrated undesirable side effects, it is possible that reduction of BACE- 1 activity in conjunction with a reduced level of oxidative stress is achievable by administering gallic acid, and this can offer a worthwhile therapeutic pathway $[123,124]$. In a mouse model of $A D$, gallic acid also reduced $\beta$-secretase activity, inhibited neuroinflammation and stabilized brain oxidative stress [125], further supporting the observations using the fly model. Other studies indicated that administration of gallic acid caused reductions in neuronal reactive oxygen species, improvement of learning and memory and improved brain electrical activity [126].

Exposure to extraction of Mulberry fruit has also shown beneficial results in reducing A $\beta$ toxicity in Drosophila AD models [127]. In extracts from mulberry fruit of Morus cf. nigra "Chiang Mai" obtained using acidic methanol, the only anthocyanin detected by the authors was cyanidin, with a content of around $250 \mathrm{ug} / \mathrm{g}$ dry weight [127]. The principal component of this extract is anthocyanin, which is a flavonoid that is naturally found in the tissues of many higher plants. Anthocyanin, similar to gallic acid, has been shown to have antioxidant properties, as well as benefits in the gastrointestinal system [128]. The study conducted by Suttisansanee showed the extract inhibiting BACE- 1 and cholinesterase activity, in addition to promoting neurite outgrowth in the neuronal cells [127]. Additionally, previous studies in mice have shown links between the administration of anthocyanin and improvement in $\mathrm{A} \beta$ clearance, reduction of inflammation and halting of neurodegeneration [129]. Furthermore, other studies have shown that anthocyanin is able to work synergistically with gallic acid in modulating BACE-1 activity, reducing inflammation and improving the clearance of $A \beta$ plaques [130]. Therefore, a combination therapy of gallic acid and anthocyanin may prove to be worth exploring to examine whether it is able to provide therapeutic benefits to $\mathrm{AD}$ patients, as both compounds are known to cross the blood-brain barrier $[131,132]$. It is worth emphasizing that whereas the studies mentioned above suggest promising and correlative results between the use of nutraceuticals and the amelioration of some AD-related phenotypes, further studies are required to confirm that the doses of nutraceuticals given to the animals are relevant to the observed biological effects. 
Although the focus of this review is on recent publications using Drosophila AD models, the studies described above represent a small fraction of nutraceutical studies not only in flies, but, even in a larger number, in rodent models [122,133,134]. For example, cinnamon and its active compound cinnamaldehyde have also shown beneficial effects on fly and mouse AD models [135-137]. Some additional nutraceuticals that have shown promising results ameliorating AD-related phenotypes (Table 1) include the flavonoid silybin B [138,139], curcumin [140], saffron [141], sulforaphane [142], iron [143,144] and other transition metals [145]. In fact, silver treatment in flies [146] represents an intriguing treatment option that requires further investigation as silver is known to have opposite effects, including antiseptic activity and reduced brain inflammation as well as neurotoxicity $[147,148]$.

Table 1. Nutraceutical compounds known to ameliorate phenotypes in animal AD models.

\begin{tabular}{|c|c|c|c|c|c|}
\hline Compound & $\begin{array}{c}\text { Preferred } \\
\text { IUPAC name }\end{array}$ & Chemical Formula & $\begin{array}{c}\text { Type of } \\
\text { Molecule }\end{array}$ & Occurrence & $\begin{array}{l}\text { References } \\
\text { (AD Models) }\end{array}$ \\
\hline Gallic acid & $\begin{array}{l}\text { 3,4,5-Trihydroxybenzoic } \\
\text { acid }\end{array}$ & & Phenolic acid & $\begin{array}{l}\text { Sumac }(R h u s) \text {, tea } \\
\text { leaves, strawberry, } \\
\text { grape }\end{array}$ & [123-125] \\
\hline Cyanidin & $\begin{array}{c}\text { 2-(3,4- } \\
\text { Dihydroxyphenyl)-3,5,7- } \\
\text { trihydroxy-1 } 1 \lambda 4- \\
\text { benzopyran-1-ylium }\end{array}$ & & Pigment & $\begin{array}{c}\text { Mulberry (Morus } \\
\text { nigra) } \\
\text { Blueberry } \\
\text { (Vaccinium) }\end{array}$ & {$[127,129,130]$} \\
\hline Cinnamaldehyde & $\begin{array}{l}\text { (2E)-3-Phenylprop-2- } \\
\text { enal }\end{array}$ & & Phenylpropanoid & Cinnamon & [135-137] \\
\hline Curcumin & $\begin{array}{l}\text { (1E,6E)-1,7-Bis(4- } \\
\text { hydroxy-3- } \\
\text { methoxyphenyl)hepta- } \\
\text { 1,6-diene-3,5-dione }\end{array}$ & & Diarylheptanoid & $\begin{array}{l}\text { Turmeric (Curcuma } \\
\text { longa) }\end{array}$ & [140] \\
\hline Silybin & $\begin{array}{c}(2 R, 3 R)-3,5,7- \\
\text { trihydroxy-2-[(2R*,3R* } \\
\text { 3-(4-hydroxy-3- } \\
\text { methoxyphenyl)-2- } \\
\text { (hydroxymethyl)-2,3- } \\
\text { dihydrobenzo[b][1,4]dioxin- } \\
\text { 6-yl]chroman-4-one }\end{array}$ & & Flavonolignan & $\begin{array}{c}\text { Milk thistle } \\
\text { (Silibum marianum) }\end{array}$ & {$[138,139]$} \\
\hline
\end{tabular}


Table 1. Cont.

\begin{tabular}{|c|c|c|c|c|c|}
\hline Compound & $\begin{array}{l}\text { Preferred } \\
\text { IUPAC name }\end{array}$ & Chemical Formula & $\begin{array}{c}\text { Type of } \\
\text { Molecule }\end{array}$ & Occurrence & $\begin{array}{l}\text { References } \\
\text { (AD Models) }\end{array}$ \\
\hline Crocin & $\begin{array}{c}\text { Bis[(2S,3R,4S,5S,6R)- } \\
3,4,5 \text {-trihydroxy-6- } \\
(\{[(2 R, 3 R, 4 S, 5 S, 6 R)-3,4,5- \\
\text { trihydroxy-6- } \\
\text { (hydroxymethyl)oxan-2- } \\
\text { yl]oxy\}methyl)oxan-2- } \\
\text { yl] } \\
(2 E, 4 E, 6 E, 8 E, 10 E, 12 E, 14 E)- \\
2,6,11,15- \\
\text { tetramethylhexadeca- } \\
2,4,6,8,10,12,14- \\
\text { heptaenedioate }\end{array}$ & & Carotenoid & Saffron & [141] \\
\hline Sulforaphane & $\begin{array}{c}\text { 1-Isothiocyanato-4- } \\
\text { (methanesulfinyl) } \\
\text { butane }\end{array}$ & & Isothiocyanate & $\begin{array}{c}\text { Broccoli } \\
\text { Brussel sprouts } \\
\text { Cabbage }\end{array}$ & [142] \\
\hline
\end{tabular}

When discussing nutraceutical approaches and AD, it is important to include the gut-brain axis and the emerging evidence of multiple interactions between gut dysbiosis and AD [149,150]. Interestingly, a recent study shows that flies raised without a bacterial microbiome failed to show the age-related increase in activation of the immune response genes and decline in expression of stress response genes observed in control flies [151]. These results indicate a crucial role of the gut microbiome in aging, since age-dependent systemic changes in gene expression, particularly stress and immune response genes, fail to happen when flies are grown axenically [151]. In murine AD models, previous literature reports that the gut microbiome can influence the neuroinflammation in AD through the production of proinflammatory cytokines (IL- $1 \beta$, IL-6, IL-18, TNF- $\alpha$ and IFN- $\gamma$ ) and bacterial metabolites [152]. Drosophila AD models show increased levels of the TNF- $\alpha$ eiger, whose downstream activator JNK causes inflammation-induced apoptosis [153]. Enteric dysbiosis by oral infection with non-pathogenic enterobacteria was induced in AD flies, which strongly exacerbated neurodegeneration via immune hemocyte recruitment to the brain. These results suggest that the gut-brain axis promotes neurodegeneration by the mobilization of hemocytes and their attraction to the diseased brain [153]. Furthermore, promising results including improvement of gut dysbiosis, altered microbiota-derived metabolites, neuroinflammation and cognition impairment were observed in AD transgenic mice and in initial clinical trials in humans after treatment with sodium oligomannate (GV971), a mixture of oligosaccharides derived from marine brown algae [154,155]. It would be interesting to test GV-971 in Drosophila AD models to further investigate its underlying molecular roles and effects in neuronal anatomy, such as spine remodeling [121] and synaptic refinement [156].

The use of probiotics has been described as an efficient strategy in the treatment of various neurological conditions [157]. A reduction in the onset and progression of disease-related phenotypes was recently described by the modulation of the gut-brain axis through probiotic treatment in AD flies [158]. A synbiotic formulation containing three bioactive probiotics (Lactobacillus plantarum NCIMB 8826 (Lp8826), L. fermentum NCIMB 5221 (Lf5221), and Bifidobacteria longum spp. infantis NCIMB 702255 (Bi702255)) and a novel polyphenol-rich prebiotic, Triphala (TFLA), improved survival, motility, A $\beta$ accumulation and acetylcholinesterase activity, likely acting through mechanisms implicating the 
peroxisome proliferator-activated receptor (PPAR) $\gamma$ [158]. In a mouse AD model, Bonfili et al. (2020) [159] investigated the effects of probiotics (SLAB51) in restoring glucose homeostasis. Glucose uptake correlates with a higher risk of developing AD and is influenced by abnormalities of AMPK and Akt. Results showed restored expression levels of glucose transporters (GLUT1 and GLUT3) and reduced phosphorylation of tau, AMPK and Akt after treatment of SLAB51 in AD mice. Moreover, SLAB51 counteracted insulin resistance and improved glucose metabolism impairment, delaying AD progression. In humans, Nagpal et al. [160] compared the effects of dietary intervention on the microbiome of normal versus mild cognitively impaired (MCI) subjects. Gut microbial signatures such as reduced SCFAs and a greater abundance of proinflammatory bacteria were present in MCI subjects. Results showed that a modified Mediterranean-ketogenic diet (MMKD) regulated the gut microbiome and the production of its metabolites, improving AD symptoms. Although there are several factors that limit these studies, such as small sample size and gender bias, the findings provide relevant information on the role of the gut microbiota-brain axis in $\mathrm{AD}$ and contribute to the development of therapeutics.

\section{Concluding Thoughts}

Alzheimer's disease has been and will continue to be a detrimental burden on the elderly population. Not only does it lead to a significant reduction in the quality of life for both patients and their families, but it also has the potential to distress the healthcare industry. Model organisms such as Drosophila have been utilized to investigate relevant molecular tools and examine subsequent phenotypes, broadening our understanding of fundamental mechanisms. In fact, besides the results described above, additional genetic screens and molecular studies in Drosophila have expanded our understanding of additional AD-associated loci [161].

Furthermore, whereas our discussion focused on the success of nutraceutical approaches (Figure 1), conclusive evidence on their validity in the treatment of human AD from clinical studies is still lacking. Besides nutraceuticals, a few treatments are worth noting based on their promising initial results in animal models, including pharmacological treatments such as histone deacetylases inhibitors [162] and angiotensin-converting enzyme inhibitors [163-165]. Additionally, whereas evidence from current clinical trials indicates beneficial effects of acetylcholinesterase inhibitors [4] and anticancer drugs in AD patients [166], the future application of genetic approaches such as gene therapy [167], including RNA-based therapy [168] and CRISPR [169] represents a new window for AD treatment. Additionally, the growing literature indicating a role of the gut microbiome in host physiology, metabolism, disease-associated phenotypes and efficacy of drug therapies underscores the relevance of this evolving research field. Despite differences between the more complex mammalian microbiome and the relatively simpler fly one, several advantages of the Drosophila gut microbiota have been reported, supporting its use as a model to study mammalian gut complexity and microbiome/drug interactions [170,171]. Future studies will determine its relevance in expanding our understanding of fundamental mechanisms underlying neurological diseases.

By contrast, it may be worth considering the role of developmental processes in AD onset and progression. This idea is supported by the observations that not only mammalian APP and Drosophila APPL play important roles in developmental processes as described above, but also other AD-associated genes and proteins are involved in neurodevelopmental processes such as neuronal migration and axon extension [172]. Finally, recent advances in molecular biology have allowed the emergence of a large body of exciting evidence linking AD-related mechanisms and epigenetics [173,174]. Several fundamental epigenetic mechanisms are conserved in flies, supporting the idea that the insight gained from Drosophila studies will likely advance the understanding of the mammalian brain, and thus be relevant to human health. 


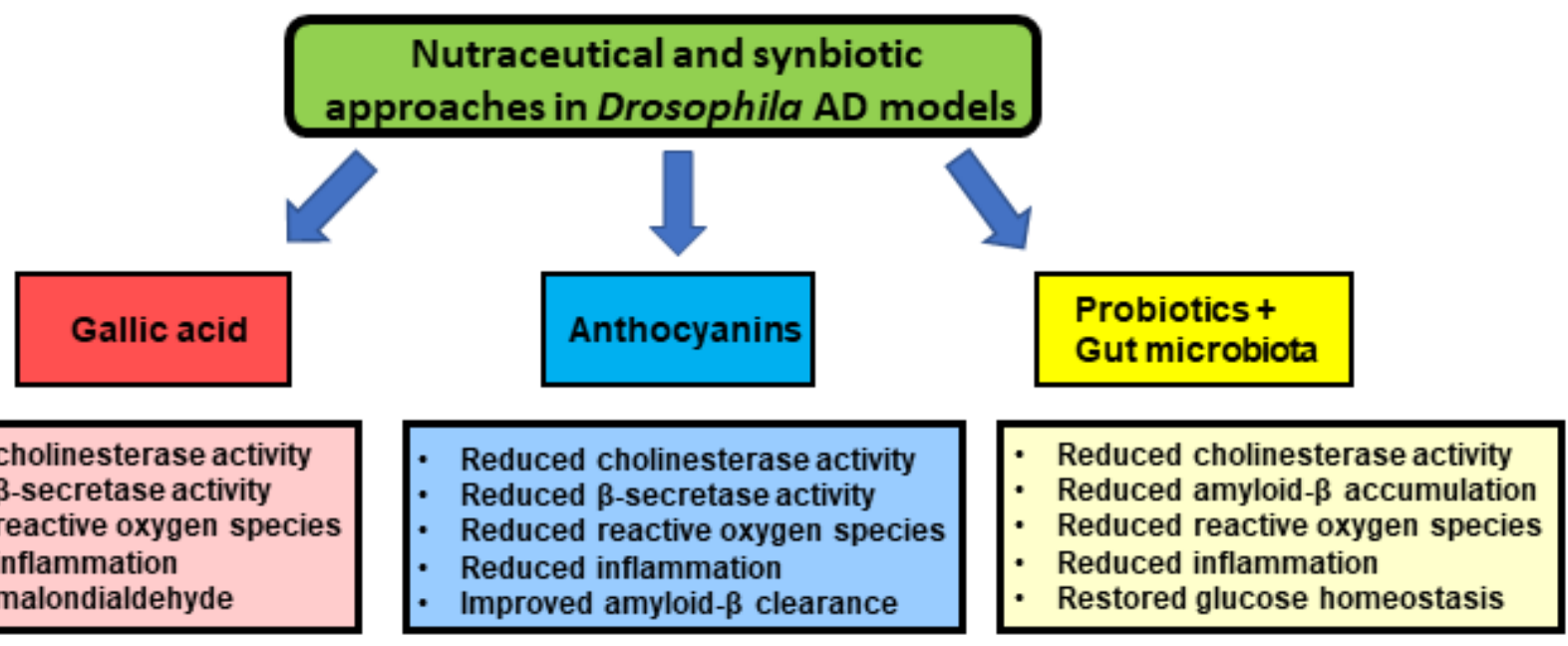

- Reduced cholinesterase activity

- Reduced $\beta$-secretase activity

- Reduced reactive oxygen species

- Reduced inflammation

- Reduced malondialdehyde
Reduced cholinesterase activity Reduced $\beta$-secretase activity
Reduced inflammation
Improved amyloid- $\beta$ clearance

\section{Reduced inflammation \\ Restored glucose homeostasis}

Figure 1. Diagram of recent nutraceutical and synbiotic approaches tested in Drosophila AD models and their molecular and cellular effects. Future studies would confirm that the doses of nutraceuticals given to the flies are relevant to the biological effects observed in the initial studies discussed in the text.

Author Contributions: D.J. and F.J.V. structured the text and content. D.J., J.A.G., L.M., L.H. and F.J.V. reviewed the literature and provided intellectual contributions. F.J.V. generated the figures. D.J., J.A.G., L.M., L.H. and F.J.V. wrote the manuscript. All authors have read and agreed to the published version of the manuscript.

Funding: Thanks to the UMBC Natural Sciences Pre-Professoriate Fellowship for support to FJV. Support to LM is from the Society for Advancement of Chicanos/Hispanics and Native Americans in Science (SACNAS)—UMBC Chapter and the LSAMP Program at UMBC, which is funded through an award from the National Science Foundation (Award \#1002566). Any opinions, findings and conclusions or recommendations expressed in this material are those of the author(s) and do not necessarily reflect the views of the National Science Foundation (NSF).

Institutional Review Board Statement: Not applicable.

Informed Consent Statement: Not applicable.

Acknowledgments: We thank Rachel Brewster and Laurie Sutton, as well as members of the Vonhoff lab for helpful comments on the manuscript.

Conflicts of Interest: The authors declare no conflict of interest.

\section{References}

1. Masters, C.L.; Bateman, R.; Blennow, K.; Rowe, C.C.; Sperling, R.A.; Cummings, J.L. Alzheimer's disease. Nat. Rev. Dis. Primers. 2015, 1, 15056. [CrossRef] [PubMed]

2. Avila, J.; Perry, G. A Multilevel View of the Development of Alzheimer's Disease. Neuroscience 2021, 457, 283-293. [CrossRef] [PubMed]

3. Livingston, G.; Huntley, J.; Sommerlad, A.; Ames, D.; Ballard, C.; Banerjee, S.; Brayne, C.; Burns, A.; Cohen-Mansfield, J.; Cooper, C.; et al. Dementia prevention, intervention, and care: 2020 report of the Lancet Commission. Lancet 2020, 396, 413-446. [CrossRef]

4. Fink, H.A.; Linskens, E.J.; MacDonald, R.; Silverman, P.C.; McCarten, J.R.; Talley, K.M.; Forte, M.L.; Desai, P.J.; Nelson, V.A.; Miller, M.A.; et al. Benefits and harms of prescription drugs and supplements for treatment of clinical Alzheimer-type dementia: A systematic review and meta-analysis. Ann. Intern. Med. 2020, 172, 656-668. [CrossRef] [PubMed]

5. Murray, M.E.; Graff-Radford, N.R.; Ross, O.A.; Petersen, R.C.; Duara, R.; Dickson, D.W. Neuropathologically defined subtypes of Alzheimer's disease with distinct clinical characteristics: A retrospective study. Lancet Neurol. 2011, 10, 785-796. [CrossRef]

6. Querfurth, H.; LaFerla, F. Alzheimer's disease. N. Engl. J. Med. 2010, 362, 1844-1845. [CrossRef]

7. Glenner, G.G.; Wong, C.W. Alzheimer's disease: Initial report of the purification and characterization of a novel cerebrovascular amyloid protein. Biochem. Biophys. Res. Commun. 1984, 120, 885-890. [CrossRef] 
8. Brion, J.P.; Passareiro, H.; Nunez, J.; Flament-Durand, J. Mise en évidence immunologique de la protéine tau au niveau des lésions de dégénérescence neurofibrillaire de la maladie d'Alzheimer. Arch. Biol. 1985, 95, 229-235.

9. Rinne, J.O.; Rummukainen, J.; Paljärvi, L.; Säkö, E.; Mölsä, P.; Rinne, U.K. Neuronal loss in the substantia nigra in patients with Alzheimer's disease and Parkinson's disease in relation to extrapyramidal symptoms and dementia. Prog. Clin. Biol. Res. 1989, $317,325-332$.

10. Bondareff, W.; Mountjoy, C.; Roth, M.; Hauser, D. Neurofibrillary degeneration and neuronal loss in alzheimer's disease. Neurobiol. Aging 1989, 10, 709-715. [CrossRef]

11. Braak, H.; Braak, E. Neuropathological stageing of Alzheimer-related changes. Acta Neuropathol. 1991, 82, 239-259. [CrossRef]

12. Braak, H.; Alafuzoff, I.; Arzberger, T.; Kretzschmar, H.; Del Tredici, K. Staging of Alzheimer disease-associated neurofibrillary pathology using paraffin sections and immunocytochemistry. Acta Neuropathol. 2006, 112, 389-404. [CrossRef]

13. Ohm, T.; Müller, H.; Braak, H.; Bohl, J. Close-meshed prevalence rates of different stages as a tool to uncover the rate of Alzheimer's disease-related neurofibrillary changes. Neuroscience 1995, 64, 209-217. [CrossRef]

14. Hardy, J. A hundred years of Alzheimer's disease research. Neuron 2006, 52, 3-13. [CrossRef]

15. Jelicic, M.; Bonebakker, A.E.; Bonke, B. Implicit memory performance of patients with Alzheimer's disease: A brief review. Int. Psychogeriatr. 1995, 7, 385-392. [CrossRef] [PubMed]

16. Förstl, H.; Kurz, A. Clinical features of Alzheimer's disease. Eur. Arch. Psychiatry Clin. Neurosci. 1999, 249, 288-290. [CrossRef] [PubMed]

17. Bäckman, L.; Jones, S.; Berger, A.K.; Laukka, E.J.; Small, B.J. Multiple cognitive deficits during the transition to Alzheimer's disease. J. Intern. Med. 2004, 256, 195-204. [CrossRef]

18. Gold, D.P.; Reis, M.F.; Markiewicz, D.; Andres, D. When Home Caregiving Ends: A Longitudinal Study of Outcomes for Caregivers of Relatives with Dementia. J. Am. Geriatr. Soc. 1995, 43, 10-16. [CrossRef]

19. Quertinmount, K.; Rizzo, B.; Swann, C.; Coram, L.; Klein, M.; Detillion, W.N. A Novel Approach to Treating Alzheimer's Disease. Pharm. Wellness Rev. 2010, 1, 17-18.

20. Jaul, E.; Meiron, O. Dementia and Pressure Ulcers: Is There a Close Pathophysiological Interrelation? J. Alzheimer's Dis. 2017, 56, 861-866. [CrossRef]

21. Dubois, B.; Hampel, H.; Feldman, H.H.; Scheltens, P.; Aisen, P.; Andrieu, S.; Bakardjian, H.; Benali, H.; Bertram, L.; Blennow, K.; et al. Preclinical Alzheimer's disease: Definition, natural history, and diagnostic criteria. Alzheimer's Dement. J. Alzheimer's Assoc. 2016, 12, 292-323. [CrossRef] [PubMed]

22. Bateman, R.J.; Xiong, C.; Benzinger, T.L.; Fagan, A.M.; Goate, A.; Fox, N.C.; Marcus, D.S.; Cairns, N.J.; Xie, X.; Blazey, T.M.; et al. Clinical and Biomarker Changes in Dominantly Inherited Alzheimer's Disease. N. Engl. J. Med. 2012, 367, 795-804. [CrossRef]

23. Fagan, A.M.; Xiong, C.; Jasielec, M.S.; Bateman, R.J.; Goate, A.; Benzinger, T.; Ghetti, B.; Martins, R.; Masters, C.L.; Mayeux, R.; et al. Longitudinal Change in CSF Biomarkers in Autosomal-Dominant Alzheimer's Disease. Sci. Transl. Med. 2014, 6, $226 \mathrm{ra30.}$ [CrossRef] [PubMed]

24. Reiman, E.M.; Langbaum, J.B.; Fleisher, A.S.; Caselli, R.J.; Chen, K.; Ayutyanont, N.; Quiroz, Y.T.; Kosik, K.S.; Lopera, F.; Tariot, P.N. Alzheimer's Prevention Initiative: A Plan to Accelerate the Evaluation of Presymptomatic Treatments. J. Alzheimer's Dis. 2011, 26, 321-329. [CrossRef] [PubMed]

25. Langbaum, J.B.; Ellison, N.N.; Caputo, A.; Thomas, R.G.; Langlois, C.; Riviere, M.-E.; Graf, A.; Lopez, C.L.; Reiman, E.M.; Tariot, P.N.; et al. The Alzheimer's Prevention Initiative Composite Cognitive Test: A practical measure for tracking cognitive decline in preclinical Alzheimer's disease. Alzheimer's Res. Ther. 2020, 12, 1-11. [CrossRef] [PubMed]

26. Arendt, T.; Stieler, J.; Ueberham, U. Is sporadic Alzheimer's disease a developmental disorder? J. Neurochem. 2017, 143, 396-408. [CrossRef]

27. Penner, G.; Lecocq, S.; Chopin, A.; Vedoya, X.; Lista, S.; Vergallo, A.; Lejeune, F.X.; Hampel, H. Blood-based diagnostics of Alzheimer's disease. Expert Rev. Mol. Diagn. 2019, 19, 613-616. [CrossRef] [PubMed]

28. Wenk, G.L. Neuropathologic changes in Alzheimer's disease. J. Clin. Psychiatry 2003, 64, 7-10.

29. Schroeter, M.L.; Stein, T.; Maslowski, N.; Neumann, J. Neural correlates of Alzheimer's disease and mild cognitive impairment: A systematic and quantitative meta-analysis involving 1351 patients. NeuroImage 2009, 47, 1196-1206. [CrossRef]

30. Yeo, J.M.; Waddell, B.; Khan, Z.; Pal, S. A systematic review and meta-analysis of (18)F-labeled amyloid imaging in Alzheimer's disease. Alzheimer's Dement. 2015, 1, 5-13. [CrossRef] [PubMed]

31. Barthel, H. First Tau PET Tracer Approved: Toward Accurate In Vivo Diagnosis of Alzheimer Disease. J. Nucl. Med. 2020, 61, 1409-1410. [CrossRef]

32. Jack, C.R., Jr.; Bennett, D.A.; Blennow, K.; Carrillo, M.C.; Dunn, B.; Haeberlein, S.B.; Holtzman, D.M.; Jagust, W.; Jessen, F.; Karlawish, J.; et al. NIA-AA research framework: Toward a biological definition of Alzheimer's disease. Alzheimers Dement. 2018, 14, 535-562. [CrossRef]

33. Zhang, X.; Alshakhshir, N.; Zhao, L. Glycolytic Metabolism, Brain Resilience, and Alzheimer's Disease. Front. Neurosci. 2021, 15. [CrossRef] [PubMed]

34. Costantini, L.C.; Barr, L.J.; Vogel, J.L.; Henderson, S.T. Hypometabolism as a therapeutic target in Alzheimer's disease. BMC Neurosci. 2008, 9, S16. [CrossRef] [PubMed]

35. Ou, Y.N.; Xu, W.; Li, J.Q.; Guo, Y.; Cui, M.; Chen, K.-L.; Huang, Y.-Y.; Dong, Q.; Tan, L.; Yu, J.-T.; et al. FDG-PET as an independent biomarker for Alzheimer's biological diagnosis: A longitudinal study. Alz Res Therapy. 2019, 11, 57. [CrossRef] 
36. Sims, N.; Smith, C.; Davison, A.; Bowen, D.; Flack, R.; Snowden, J.; Neary, D. Glucose metabolism and acetylcholine synthesis in relation to neuronal activity in alzheimer's disease. Lancet 1980, 315, 333-336. [CrossRef]

37. Iwangoff, P.; Armbruster, R.; Enz, A.; Meier-Ruge, W. Glycolytic enzymes from human autoptic brain cortex: Normal aged and demented cases. Mech. Ageing Dev. 1980, 14, 203-209. [CrossRef]

38. Hoyer, S. Causes and Consequences of Disturbances of Cerebral Glucose Metabolism in Sporadic Alzheimer Disease: Therapeutic Implications. Adv. Exp. Med. Biol. 2004, 541, 135-152. [CrossRef]

39. De La Monte, S.M.; Wands, J.R. Alzheimer's Disease is Type 3 Diabetes-Evidence Reviewed. J. Diabetes Sci. Technol. 2008, 2, 1101-1113. [CrossRef] [PubMed]

40. Fyfe, I. Brain organoids shed light on APOE genotype and Alzheimer disease pathology. Nat. Rev. Neurol. 2021, 17, 1. [CrossRef]

41. Papaspyropoulos, A.; Tsolaki, M.; Foroglou, N.; Pantazaki, A.A. Modeling and Targeting Alzheimer's Disease With Organoids. Front. Pharmacol. 2020, 11, 396. [CrossRef] [PubMed]

42. Venkataraman, L.; Fair, S.R.; McElroy, C.A.; Hester, M.E.; Fu, H. Modeling neurodegenerative diseases with cerebral organoids and other three-dimensional culture systems: Focus on Alzheimer's disease. Stem Cell Rev. Rep. 2020, 1-22. [CrossRef] [PubMed]

43. Alzheimer, A.; Stelzmann, R.A.; Schnitzlein, H.N.; Murtagh, F.R. An English translatio of Alzheimer's 1907 paper, “Uber eine eigenartige Erkankung der Hirnrinde". Clin Anat. 1995, 8, 429-431. [PubMed]

44. Bloom, G.S. Amyloid- $\beta$ and tau: The trigger and bullet in Alzheimer disease pathogenesis. JAMA Neurol. 2014, 71, 505-508. [CrossRef]

45. Goedert, M.; Wischik, C.M.; Crowther, R.A.; Walker, J.; Klug, A. Cloning and sequencing of the cDNA encoding a core protein of the paired helical filament of Alzheimer disease: Identification as the microtubule-associated protein tau. Proc. Natl. Acad. Sci. USA 1988, 85, 4051-4055. [CrossRef]

46. Lei, P.; Ayton, S.; Finkelstein, D.I.; Adlard, P.A.; Masters, C.L.; Bush, A.I. Tau protein: Relevance to Parkinson's disease. Int. J. Biochem. Cell Biol. 2010, 42, 1775-1778. [CrossRef]

47. Jack, C.R., Jr.; Petersen, R.C.; Xu, Y.C.; O’Brien, P.C.; Smith, G.E.; Ivnik, R.J.; Boeve, B.F.; Waring, S.C.; Tangalos, E.G.; Kokmen, E. Prediction of AD with MRI-based hippocampal volume in mild cognitive impairment. Neurology 1999, 52, 1397-1403. [CrossRef]

48. DeTure, M.A.; Dickson, D.W. The neuropathological diagnosis of Alzheimer's disease. Mol. Neurodegener. 2019, 14, 1-18. [CrossRef]

49. Subramanian, J.; Savage, J.C.; Tremblay, M.-E. Synaptic Loss in Alzheimer's Disease: Mechanistic Insights Provided by TwoPhoton in vivo Imaging of Transgenic Mouse Models. Front. Cell. Neurosci. 2020, 14. [CrossRef]

50. Meyer-Luehmann, M.; Spires-Jones, T.; Prada, C.; Garcia-Alloza, M.; De Calignon, A.; Rozkalne, A.; Koenigsknecht-Talboo, J.; Holtzman, D.M.; Bacskai, B.J.; Hyman, B.T. Rapid appearance and local toxicity of amyloid- $\beta$ plaques in a mouse model of Alzheimer's disease. Nat. Cell Biol. 2008, 451, 720-724. [CrossRef]

51. Blazquez-Llorca, L.; Valero-Freitag, S.; Rodrigues, E.F.; Merchán-Pérez, Á.; Rodriguez, J.-R.; Dorostkar, M.M.; DeFelipe, J.; Herms, J. High plasticity of axonal pathology in Alzheimer's disease mouse models. Acta Neuropathol. Commun. 2017, 5, 14. [CrossRef]

52. Peters, F.; Salihoglu, H.; Rodrigues, E.; Herzog, E.; Blume, T.; Filser, S.; Dorostkar, M.; Shimshek, D.R.; Brose, N.; Neumann, U.; et al. BACE1 inhibition more effectively suppresses initiation than progression of $\beta$-amyloid pathology. Acta Neuropathol. 2018, 135, 695-710. [CrossRef] [PubMed]

53. Busche, M.A.; Hyman, B.T. Synergy between amyloid- $\beta$ and tau in Alzheimer's disease. Nat. Neurosci. 2020, $23,1183-1193$. [CrossRef] [PubMed]

54. Vilchez, D.; Saez, I.; Dillin, A. The role of protein clearance mechanisms in organismal ageing and age-related diseases. Nat. Commun. 2014, 5, 5659. [CrossRef]

55. Turner, P.R.; O'Connor, K.; Tate, W.P.; Abraham, W.C. Roles of amyloid precursor protein and its fragments in regulating neural activity, plasticity and memory. Prog. Neurobiol. 2003, 70, 1-32. [CrossRef]

56. Muller-Hill, B.; Beyreuther, K. Molecular biology ofAlzheimer's disease. Annu. Rev. Biochem. 1989, 58, 287-307. [CrossRef]

57. Priller, C.; Bauer, T.; Mitteregger, G.; Krebs, B.; Kretzschmar, H.A.; Herms, J. Synapse Formation and Function Is Modulated by the Amyloid Precursor Protein. J. Neurosci. 2006, 26, 7212-7221. [CrossRef]

58. Zheng, H.; Koo, E.H. The amyloid precursor protein: Beyond amyloid. Mol. Neurodegener. 2006, 1, 5. [CrossRef]

59. Dawkins, E.; Small, D.H. Insights into the physiological function of the $\beta$-amyloid precursor protein: Beyond Alzheimer's disease. J. Neurochem. 2014, 129, 756-769. [CrossRef] [PubMed]

60. Li Puma, D.D.; Piacentini, R.; Grassi, C. Does Impairment of Adult Neurogenesis Contribute to Pathophysiology of Alzheimer's Disease? A Still Open Question. Front. Mol. Neurosci. 2021, 13. [CrossRef]

61. Porayette, P.; Gallego, M.J.; Kaltcheva, M.M.; Meethal, S.V.; Atwood, C.S. Amyloid- $\beta$ precursor protein expression and modulation in human embryonic stem cells: A novel role for human chorionic gonadotropin. Biochem. Biophys. Res. Commun. 2007, 364, 522-527. [CrossRef]

62. Lamb, B.T.; Sisodia, S.S.; Lawler, A.M.; Slunt, H.H.; Kitt, C.A.; Kearns, W.G.; Pearson, P.L.; Price, D.L.; Gearhart, J.D. Introduction and expression of the 400 kilobase precursor amyloid protein gene in transgenic mice. Nat. Genet. 1993, 5, 22-30. [CrossRef]

63. Nalivaeva, N.N.; Turner, A.J. The amyloid precursor protein: A biochemical enigma in brain development, function and disease. FEBS Lett. 2013, 587, 2046-2054. [CrossRef] [PubMed]

64. Akasaka-Manya, K.; Manya, H. The Role of APP O-Glycosylation in Alzheimer's Disease. Biomolecules 2020, 10, 1569. [CrossRef] [PubMed] 
65. Das, B.; Yan, R. A Close Look at BACE1 Inhibitors for Alzheimer's Disease Treatment. CNS Drugs 2019, 33, 251-263. [CrossRef] [PubMed]

66. Zhao, J.; Deng, Y.; Jiang, Z.; Qing, H. G protein-coupled receptors (GPCRs) in Alzheimer's disease: A focus on BACE1 related GPCRs. Front. Aging Neurosci. 2016, 8, 58. [CrossRef]

67. Nistor, M.; Don, M.; Parekh, M.; Sarsoza, F.; Goodus, M.; Lopez, G.; Kawas, C.; Leverenz, J.; Doran, E.; Lott, I.; et al. Alpha- and beta-secretase activity as a function of age and beta-amyloid in Down syndrome and normal brain. Neurobiol. Aging 2007, 28, 1493-1506. [CrossRef]

68. Hartley, D.; Blumenthal, T.; Carrillo, M.; Di Paolo, G.; Esralew, L.; Gardiner, K.; Granholm, A.C.; Iqbal, K.; Krams, M.; Lemere, C.; et al. Down syndrome and Alzheimer's disease: Common pathways, common goals. Alzheimer's Dement. 2015, 11, 700-709. [CrossRef] [PubMed]

69. Matsui, T.; Ingelsson, M.; Fukumoto, H.; Ramasamy, K.; Kowa, H.; Frosch, M.P.; Irizarry, M.C.; Hyman, B.T. Expression of APP pathway mRNAs and proteins in Alzheimer's disease. Brain Res. 2007, 1161, 116-123. [CrossRef]

70. Haass, C.; Lemere, C.A.; Capell, A.; Citron, M.; Seubert, P.; Schenk, D.; Lannfelt, L.; Selkoe, D.J. The Swedish mutation causes early-onset Alzheimer's disease by $\beta$-secretase cleavage within the secretory pathway. Nat. Med. 1995, 1, 1291-1296. [CrossRef]

71. Li, N.-M.; Liu, K.-F.; Qiu, Y.-J.; Zhang, H.-H.; Nakanishi, H. Mutations of beta-amyloid precursor protein alter the consequence of Alzheimer's disease pathogenesis. Neural. Regen. Res. 2019, 14, 658-665. [CrossRef] [PubMed]

72. Nilsberth, C.; Westlind-Danielsson, A.; Eckman, C.B.; Condron, M.M.; Axelman, K.; Forsell, C.; Stenh, C.; Luthman, J.; Teplow, D.B.; Younkin, S.G.; et al. The 'Arctic' APP mutation (E693G) causes Alzheimer's disease by enhanced A $\beta$ protofibril formation. Nat. Neurosci. 2001, 4, 887-893. [CrossRef]

73. Westerman, M.A.; Cooper-Blacketer, D.; Mariash, A.; Kotilinek, L.; Kawarabayashi, T.; Younkin, L.H.; Carlson, G.A.; Younkin, S.G.; Ashe, K.H. The relationship between A $\beta$ and memory in the Tg2576 mouse model of Alzheimer's disease. J. Neurosci. 2002, 22, 1858-1867. [CrossRef]

74. Jonsson, T.; Atwal, J.K.; Steinberg, S.; Snaedal, J.; Jonsson, P.V.; Bjornsson, S.; Stefansson, H.; Sulem, P.; Gudbjartsson, D.F.; Maloney, J.; et al. A mutation in APP protects against Alzheimer's disease and age-related cognitive decline. Nature 2012, 488, 96-99. [CrossRef]

75. Kero, M.; Paetau, A.; Polvikoski, T.; Tanskanen, M.; Sulkava, R.; Jansson, L.; Myllykangas, L.; Tienari, P.J. Amyloid precursor protein (APP) A673T mutation in the elderly Finnish population. Neurobiol. Aging 2013, 34, 1518.e1-1518.e3. [CrossRef] [PubMed]

76. Wang, L.S.; Naj, A.C.; Graham, R.R.; Crane, P.K.; Kunkle, B.W.; Cruchaga, C.; Murcia, J.D.G.; Cannon-Albright, L.; Baldwin, C.T.; Zetterberg, H.; et al. Rarity of the Alzheimer Disease-Protective APP A673T Variant in the United States. JAMA Neurol. 2015, 72, 209-216. [CrossRef]

77. Maloney, J.A.; Bainbridge, T.; Gustafson, A.; Zhang, S.; Kyauk, R.; Steiner, P.; van der Brug, M.; Liu, Y.; Ernst, J.A.; Watts, R.J.; et al. Molecular Mechanisms of Alzheimer Disease Protection by the A673T Allele of Amyloid Precursor Protein. J. Biol. Chem. 2014, 289, 30990-31000. [CrossRef] [PubMed]

78. Kokawa, A.; Ishihara, S.; Fujiwara, H.; Nobuhara, M.; Iwata, M.; Ihara, Y.; Funamoto, S. The A673T mutation in the amyloid precursor protein reduces the production of $\beta$-amyloid protein from its $\beta$-carboxyl terminal fragment in cells. Acta Neuropathol. Commun. 2015, 3, 1-12. [CrossRef]

79. Limegrover, C.S.; LeVine, H.; Izzo, N.J.; Yurko, R.; Mozzoni, K.; Rehak, C.; Sadlek, K.; Safferstein, H.; Catalano, S.M. Alzheimer's protection effect of A673T mutation may be driven by lower A $\beta$ oligomer binding affinity. J. Neurochem. 2021, 157, 1316-1330. [CrossRef] [PubMed]

80. Tambini, M.D.; Norris, K.; D'Adamio, L. Opposite changes in APP processing and human A $\beta$ levels in rats carrying either a protective or a pathogenic APP mutation. eLife 2020, 9. [CrossRef] [PubMed]

81. Cassar, M.; Kretzschmar, D. Analysis of Amyloid Precursor Protein Function in Drosophila melanogaster. Front. Mol. Neurosci. 2016, 9, 61. [CrossRef] [PubMed]

82. Copenhaver, P.F.; Kögel, D. Role of APP Interactions with Heterotrimeric G Proteins: Physiological Functions and Pathological Consequences. Front. Mol. Neurosci. 2017, 10, 3. [CrossRef]

83. Southan, C.; Hancock, J.M. A tale of two drug targets: The evolutionary history of BACE1 and BACE2. Front. Genet. 2013, 4, 293. [CrossRef] [PubMed]

84. Wong, Y.Y.; Le, P.; Elkhatib, W.; Piekut, T.; Senatore, A. Transcriptome profiling of Trichoplax adhaerens highlights its digestive epithelium and a rich set of genes for fast electrogenic and slow neuromodulatory cellular signaling. Res. Sq. 2019. in preprint research square.

85. Kaiser, T.; Feng, G. Modeling psychiatric disorders for developing effective treatments. Nat. Med. 2015, 21, 979-988. [CrossRef] [PubMed]

86. Vonhoff, F.; Williams, A.; Ryglewski, S.; Duch, C. Drosophila as a Model for MECP2 Gain of Function in Neurons. PLoS ONE 2012, 7, e31835. [CrossRef]

87. Ugur, B.; Chen, K.; Bellen, H.J. Drosophila tools and assays for the study of human diseases. Dis. Models Mechanisms 2016, 9 , 235-244. [CrossRef]

88. Bolus, H.; Crocker, K.; Boekhoff-Falk, G.; Chtarbanova, S. Modeling Neurodegenerative Disorders in Drosophila melanogaster. Int. J. Mol. Sci. 2020, 21, 3055. [CrossRef] 
89. Luo, L.Q.; Martin-Morris, L.; White, K. Identification, secretion, and neural expression of APPL, a Drosophila protein similar to human amyloid protein precursor. J. Neurosci. 1990, 10, 3849-3861. [CrossRef]

90. Guo, Q.; Wang, Z.; Li, H.; Wiese, M.; Zheng, H. APP physiological and pathophysiological functions: Insights from animal models. Cell Res. 2011, 22, 78-89. [CrossRef]

91. Poeck, B.; Strauss, R.; Kretzschmar, D. Analysis of amyloid precursor protein function in Drosophila melanogaster. Exp. Brain Res. 2011, 217, 413-421. [CrossRef]

92. Nicolas, M.; Hassan, B.A. Amyloid precursor protein and neural development. Development 2014, 141, 2543-2548. [CrossRef] [PubMed]

93. Carmine-Simmen, K.; Proctor, T.; Tschäpe, J.; Poeck, B.; Triphan, T.; Strauss, R.; Kretzschmar, D. Neurotoxic effects induced by the Drosophila amyloid- $\beta$ peptide suggest a conserved toxic function. Neurobiol. Dis. 2009, 33, 274-281. [CrossRef] [PubMed]

94. Bolkan, B.J.; Triphan, T.; Kretzschmar, D. -Secretase Cleavage of the Fly Amyloid Precursor Protein Is Required for Glial Survival. J. Neurosci. 2012, 32, 16181-16192. [CrossRef]

95. Luo, L.; Tully, T.; White, K. Human amyloid precursor protein ameliorates behavioral deficit of flies deleted for appl gene. Neuron 1992, 9, 595-605. [CrossRef]

96. Fernandez-Funez, P.; de Mena, L.; Rincon-Limas, D.E. Modeling the complex pathology of Alzheimer's disease in Drosophila. Exp. Neurol. 2015, 274, 58-71. [CrossRef]

97. Prüßing, K.; Voigt, A.; Schulz, J.B. Drosophila melanogaster as a model organism for Alzheimer's disease. Mol. Neurodegener. 2013, 8, 35. [CrossRef]

98. Li, M.; Ping, Y. Regulation of Sleep Behavior by Overexpression of Amyloid Precursor Protein in Drosophila Neurons. J. Shanghai Jiaotong Univ. 2021, 26, 63-68. [CrossRef]

99. Cordone, S.; Scarpelli, S.; Alfonsi, V.; De Gennaro, L.; Gorgoni, M. Sleep-Based Interventions in Alzheimer's Disease: Promising Approaches from Prevention to Treatment along the Disease Trajectory. Pharmaceuticals. 2021, 14, 383. [CrossRef]

100. Holth, J.K.; Patel, T.K.; Holtzman, D.M. Sleep in Alzheimer's disease-beyond amyloid. Neurobiol. Sleep Circadian Rhythm. 2017, 2, 4-14. [CrossRef]

101. Chakravarti, L.; Moscato, E.; Kayser, M. Unraveling the Neurobiology of Sleep and Sleep Disorders Using Drosophila. Planar Cell Polarity Dur. Dev. 2017, 121, 253-285. [CrossRef]

102. Kayser, M.S.; Biron, D. Sleep and Development in Genetically Tractable Model Organisms. Genetics 2016, 203, 21-33. [CrossRef]

103. Donelson, N.C.; Sanyal, S. Use of Drosophila in the investigation of sleep disorders. Exp. Neurol. 2015, 274, 72-79. [CrossRef] [PubMed]

104. Shukla, A.; Spurrier, J.; Kuzina, I.; Giniger, E. Hyperactive Innate Immunity Causes Degeneration of Dopamine Neurons upon Altering Activity of Cdk5. Cell Rep. 2019, 26, 131-144.e4. [CrossRef] [PubMed]

105. Shukla, A.; Giniger, E. Reduced autophagy efficiency induces innate immune activation leading to neurodegeneration. Autophagy 2019, 15, 1117-1119. [CrossRef]

106. Gjoneska, E.; Pfenning, A.R.; Mathys, H.; Quon, G.; Kundaje, A.; Tsai, L.-H.; Kellis, M. Conserved epigenomic signals in mice and humans reveal immune basis of Alzheimer's disease. Nat. Cell Biol. 2015, 518, 365-369. [CrossRef] [PubMed]

107. Zhuang, L.; Peng, F.; Huang, Y.; Li, W.; Huang, J.; Chu, Y.; Ren, P.; Sun, Y.; Zhang, Y.; Xue, E.; et al. CHIP modulates APP-induced autophagy-dependent pathological symptoms in Drosophila. Aging Cell 2019, 19, e13070. [CrossRef] [PubMed]

108. Paul, I.; Ghosh, M.K. The E3 ligase CHIP: Insights into its structure and regulation. BioMed Res. Int. 2014, 918183. [CrossRef]

109. Silva, B.; Niehage, C.; Maglione, M.; Hoflack, B.; Sigrist, S.J.; Wassmer, T.; Pavlowsky, A.; Preat, T. Interactions between amyloid precursor protein-like (APPL) and MAGUK scaffolding proteins contribute to appetitive long-term memory in Drosophila melanogaster. J. Neurogenet. 2020, 34, 92-105. [CrossRef]

110. Goguel, V.; Belair, A.-L.; Ayaz, D.; Lampin-Saint-Amaux, A.; Scaplehorn, N.; Hassan, B.A.; Preat, T. Drosophila Amyloid Precursor Protein-Like Is Required for Long-Term Memory. J. Neurosci. 2011, 31, 1032-1037. [CrossRef]

111. Preat, T.; Goguel, V. Role of Drosophila Amyloid Precursor Protein in Memory Formation. Front. Mol. Neurosci. 2016, 9, 142. [CrossRef] [PubMed]

112. Senechal, Y.; Kelly, P.H.; Dev, K.K. Amyloid precursor protein knockout mice show age-dependent deficits in passive avoidance learning. Behav. Brain Res. 2008, 186, 126-132. [CrossRef]

113. Soldano, A.; Okray, Z.; Janovská, P.; Tmejová, K.; Reynaud, E.; Claeys, A.; Yan, J.; Atak, Z.K.; De Strooper, B.; Dura, J.-M.; et al. The Drosophila Homologue of the Amyloid Precursor Protein Is a Conserved Modulator of Wnt PCP Signaling. PLoS Biol. 2013, 11, e1001562. [CrossRef]

114. Marquilly, C.; Busto, G.U.; Leger, B.S.; Boulanger, A.; Giniger, E.; Walker, J.A.; Fradkin, L.G.; Dura, J.-M. Htt is a repressor of Abl activity required for APP-induced axonal growth. PLoS Genet. 2021, 17, e1009287. [CrossRef]

115. Kessissoglou, I.A.; Langui, D.; Hasan, A.; Maral, M.; Dutta, S.B.; Hiesinger, P.R.; Hassan, B.A. The Drosophila amyloid precursor protein homologue mediates neuronal survival and neuroglial interactions. PLoS Biol. 2020, 18, e3000703. [CrossRef]

116. Koike, M.A.; Lin, A.J.; Pham, J.; Nguyen, E.; Yeh, J.J.; Rahimian, R.; Tromberg, B.J.; Choi, B.; Green, K.N.; LaFerla, F.M. APP Knockout Mice Experience Acute Mortality as the Result of Ischemia. PLoS ONE 2012, 7, e42665. [CrossRef]

117. Doody, R.S.; Raman, R.; Farlow, M.; Iwatsubo, T.; Vellas, B.; Joffe, S.; Kieburtz, K.; He, F.; Sun, X.; Thomas, R.G.; et al. A phase 3 trial of semagacestat for treatment of Alzheimer's disease. N. Engl. J. Med. 2013, 369, 341-350. [CrossRef] [PubMed] 
118. Egan, M.F.; Mukai, Y.; Voss, T.; Kost, J.; Stone, J.; Furtek, C.; Mahoney, E.; Cummings, J.L.; Tariot, P.N.; Aisen, P.S.; et al. Further analyses of the safety of verubecestat in the phase $3 \mathrm{EPOCH}$ trial of mild-to-moderate Alzheimer's disease. Alzheimer's Res. Ther. 2019, 11, 1-12. [CrossRef]

119. Sperling, R.; Henley, D.; Aisen, P.S.; Raman, R.; Donohue, M.C.; Ernstrom, K.; Rafii, M.S.; Streffer, J.; Shi, Y.; Karcher, K.; et al. Findings of efficacy, safety, and biomarker outcomes of atabecestat in preclinical Alzheimer disease: A truncated randomized phase 2b/3 clinical trial. JAMA Neurol. 2021, 78, 293-301. [CrossRef]

120. Ettcheto, M.; Busquets, O.; Espinosa-Jiménez, T.; Verdaguer, E.; Auladell, C.; Camins, A. A Chronological Review of Potential Disease-Modifying Therapeutic Strategies for Alzheimer's Disease. Curr. Pharm. Des. 2020, 26, 1286-1299. [CrossRef] [PubMed]

121. Ettcheto, M.; Busquets, O.; Cano, A.; Sánchez-Lopez, E.; Manzine, P.R.; Espinosa-Jimenez, T.; Verdaguer, E.; Sureda, F.X.; Olloquequi, J.; Castro-Torres, R.D.; et al. Pharmacological Strategies to Improve Dendritic Spines in Alzheimer's Disease. J. Alzheimer's Dis. 2021, 82, S91-S107. [CrossRef] [PubMed]

122. Cheng, X.; Song, C.; Du, Y.; Gaur, U.; Yang, M. Pharmacological Treatment of Alzheimer's Disease: Insights from Drosophila melanogaster. Int. J. Mol. Sci. 2020, 21, 4621. [CrossRef] [PubMed]

123. Ogunsuyi, O.B.; Oboh, G.; Oluokun, O.O.; Ademiluyi, A.O.; Ogunruku, O.O. Gallic acid protects against neurochemical alterations in transgenic Drosophila model of Alzheimer's disease. Adv. Tradit. Med. 2020, 20, 89-98. [CrossRef]

124. Hajipour, S.; Sarkaki, A.; Farbood, Y.; Eidi, A.; Mortazavi, P.; Valizadeh, Z. Effect of Gallic Acid on Dementia Type of Alzheimer Disease in Rats: Electrophysiological and Histological Studies. Basic Clin. Neurosci. J. 2016, 7, 97-106. [CrossRef] [PubMed]

125. Mori, T.; Koyama, N.; Yokoo, T.; Segawa, T.; Maeda, M.; Sawmiller, D.; Tan, J.; Town, T. Gallic acid is a dual $\alpha / \beta$-secretase modulator that reverses cognitive impairment and remediates pathology in Alzheimer mice. J. Biol. Chem. 2020, 295, 16251-16266. [CrossRef]

126. Gao, J.; Hu, J.; Hu, D.; Yang, X. A Role of Gallic Acid in Oxidative Damage Diseases: A Comprehensive Review. Nat. Prod. Commun. 2019, 14, 1934578-19874174. [CrossRef]

127. Suttisansanee, U.; Charoenkiatkul, S.; Jongruaysup, B.; Tabtimsri, S.; Siriwan, D.; Temviriyanukul, P. Mulberry fruit cultivar 'Chiang Mai'prevents beta-amyloid toxicity in PC12 neuronal cells and in a Drosophila model of Alzheimer's disease. Molecules 2020, 25, 1837. [CrossRef]

128. McDougall, G.J.; Fyffe, S.; Dobson, P.; Stewart, D. Anthocyanins from red cabbage - stability to simulated gastrointestinal digestion. Phytochemistry 2007, 68, 1285-1294. [CrossRef]

129. Shih, P.-H.; Chan, Y.-C.; Liao, J.-W.; Wang, M.-F.; Yen, G.-C. Antioxidant and cognitive promotion effects of anthocyanin-rich mulberry (Morus atropurpurea L.) on senescence-accelerated mice and prevention of Alzheimer's disease. J. Nutr. Biochem. 2010, 21, 598-605. [CrossRef]

130. Roidoung, S.; Dolan, K.D.; Siddiq, M. Gallic acid as a protective antioxidant against anthocyanin degradation and color loss in vitamin-C fortified cranberry juice. Food Chem. 2016, 210, 422-427. [CrossRef]

131. Fornasaro, S.; Ziberna, L.; Gasperotti, M.; Tramer, F.; Vrhovšek, U.; Mattivi, F.; Passamonti, S. Determination of cyanidin 3glucoside in rat brain, liver and kidneys by UPLC/MS-MS and its application to a short-term pharmacokinetic study. Sci. Rep. 2016, 6, 22815. [CrossRef] [PubMed]

132. Pervin, M.; Unno, K.; Nakagawa, A.; Takahashi, Y.; Iguchi, K.; Yamamoto, H.; Hoshino, M.; Hara, A.; Takagaki, A.; Nanjo, F.; et al. Blood brain barrier permeability of (-)-epigallocatechin gallate, its proliferation-enhancing activity of human neuroblastoma SH-SY5Y cells, and its preventive effect on age-related cognitive dysfunction in mice. Biochem. Biophys. Rep. 2017, 9, 180-186. [CrossRef]

133. Thelen, M.; Brown-Borg, H.M. Does Diet Have a Role in the Treatment of Alzheimer's Disease? Front. Aging Neurosci. $2020,12$. [CrossRef] [PubMed]

134. Gruendler, R.; Hippe, B.; Jengic, V.S.; Peterlin, B.; Haslberger, A.G. Nutraceutical Approaches of Autophagy and Neuroinflammation in Alzheimer's Disease: A Systematic Review. Molecules 2020, 25, 6018. [CrossRef]

135. Frydman-Marom, A.; Levin, A.; Farfara, D.; Benromano, T.; Scherzer-Attali, R.; Peled, S.; Vassar, R.; Segal, D.; Gazit, E.; Frenkel, D.; et al. Orally administrated cinnamon extract reduces $\beta$-amyloid oligomerization and corrects cognitive impairment in Alzheimer's disease animal models. PLoS ONE 2011, 6, e16564. [CrossRef]

136. Pham, H.M.; Xu, A.; Schriner, S.E.; Sevrioukov, E.A.; Jafari, M. Cinnamaldehyde Improves Lifespan and Healthspan in Drosophila melanogaster Models for Alzheimer's Disease. BioMed Res. Int. 2018, 2018, 1-9. [CrossRef]

137. Momtaz, S.; Hassani, S.; Khan, F.; Ziaee, M.; Abdollahi, M. Cinnamon, a promising prospect towards Alzheimer's disease. Pharmacol. Res. 2018, 130, 241-258. [CrossRef] [PubMed]

138. García-Viñuales, S.; Ahmed, R.; Sciacca, M.F.M.; Lanza, V.; Giuffrida, M.L.; Zimbone, S.; Romanucci, V.; Zarrelli, A.; Bongiorno, C.; Spinella, N.; et al. Trehalose Conjugates of Silybin as Prodrugs for Targeting Toxic A $\beta$ Aggregates. ACS Chem. Neurosci. 2020, 11, 2566-2576. [CrossRef] [PubMed]

139. Sciacca, M.F.M.; Romanucci, V.; Zarrelli, A.; Monaco, I.; Lolicato, F.; Spinella, N.; Galati, C.; Grasso, G.; D’Urso, L.; Romeo, M.; et al. Inhibition of A $\beta$ Amyloid Growth and Toxicity by Silybins: The Crucial Role of Stereochemistry. ACS Chem. Neurosci. 2017, 8, 1767-1778. [CrossRef] [PubMed]

140. Shabbir, U.; Rubab, M.; Tyagi, A.; Oh, D.-H. Curcumin and Its Derivatives as Theranostic Agents in Alzheimer's Disease: The Implication of Nanotechnology. Int. J. Mol. Sci. 2020, 22, 196. [CrossRef] 
141. Saeedi, M.; Rashidy-Pour, A. Association between chronic stress and Alzheimer's disease: Therapeutic effects of Saffron. Biomed. Pharmacother. 2021, 133, 110995. [CrossRef] [PubMed]

142. Kim, J. Pre-Clinical Neuroprotective Evidences and Plausible Mechanisms of Sulforaphane in Alzheimer's Disease. Int. J. Mol. Sci. 2021, 22, 2929. [CrossRef]

143. Massie, H.R.; Aiello, V.R.; Williams, T.R. Iron accumulation during development and ageing of Drosophila. Mech. Ageing Dev. 1985, 29, 215-220. [CrossRef]

144. Lumsden, A.; Rogers, J.; Majd, S.; Newman, M.; Sutherland, G.T.; Verdile, G.; Lardelli, M. Dysregulation of Neuronal Iron Homeostasis as an Alternative Unifying Effect of Mutations Causing Familial Alzheimer's Disease. Front. Neurosci. 2018, 12, 533. [CrossRef]

145. Li, S.; Kerman, K. Electrochemical biosensors for biometal-protein interactions in neurodegenerative diseases. Biosens. Bioelectron. 2021, 179, 113035. [CrossRef] [PubMed]

146. Alaraby, M.; Romero, S.; Hernandez, A.; Marcos, R. Toxic and Genotoxic Effects of Silver Nanoparticles in Drosophila. Environ. Mol. Mutagen. 2019, 60, 277-285. [CrossRef] [PubMed]

147. Greish, K.; Alqahtani, A.A.; Alotaibi, A.F.; Abdulla, A.M.; Bukelly, A.T.; Alsobyani, F.M.; Alharbi, G.H.; Alkiyumi, I.S.; Aldawish, M.M.; Alshahrani, T.F.; et al. The Effect of Silver Nanoparticles on Learning, Memory and Social Interaction in BALB/C Mice. Int. J. Environ. Res. Public Health 2019, 16, 148. [CrossRef]

148. Gonzalez-Carter, D.A.; Leo, B.F.; Ruenraroengsak, P.; Chen, S.; Goode, A.E.; Theodorou, I.; Chung, K.F.; Carzaniga, R.; Shaffer, M.S.P.; Dexter, D.T.; et al. Silver nanoparticles reduce brain inflammation and related neurotoxicity through induction of H2S-synthesizing enzymes. Sci. Rep. 2017, 7, 42871. [CrossRef]

149. Carranza-Naval, M.J.; Vargas-Soria, M.; Hierro-Bujalance, C.; Baena-Nieto, G.; Garcia-Alloza, M.; Infante-Garcia, C.; del Marco, A. Alzheimer's Disease and Diabetes: Role of Diet, Microbiota and Inflammation in Preclinical Models. Biomolecules 2021, 11, 262. [CrossRef]

150. Shabbir, U.; Arshad, M.; Sameen, A.; Oh, D.-H. Crosstalk between Gut and Brain in Alzheimer's Disease: The Role of Gut Microbiota Modulation Strategies. Nutrients 2021, 13, 690. [CrossRef]

151. Shukla, A.K.; Johnson, K.; Giniger, E. Common features of aging fail to occur in Drosophila raised without a bacterial microbiome. iScience 2021. [CrossRef]

152. Borsom, E.; Lee, K.; Cope, E. Do the Bugs in Your Gut Eat Your Memories? Relationship between Gut Microbiota and Alzheimer's Disease. Brain Sci. 2020, 10, 814. [CrossRef] [PubMed]

153. Wu, S.-C.; Cao, Z.-S.; Chang, K.-M.; Juang, J.-L. Intestinal microbial dysbiosis aggravates the progression of Alzheimer's disease in Drosophila. Nat. Commun. 2017, 8, 1-9. [CrossRef]

154. Wang, X.; Sun, G.; Feng, T.; Zhang, J.; Huang, X.; Wang, T.; Xie, Z.; Chu, X.; Yang, J.; Wang, H.; et al. Sodium oligomannate therapeutically remodels gut microbiota and suppresses gut bacterial amino acids-shaped neuroinflammation to inhibit Alzheimer's disease progression. Cell Res. 2019, 29, 787-803. [CrossRef] [PubMed]

155. Xiao, S.; Chan, P.; Wang, T.; Hong, Z.; Wang, S.; Kuang, W.; He, J.; Pan, X.; Zhou, Y.; Ji, Y.; et al. A 36-week multicenter, randomized, double-blind, placebo-controlled, parallel-group, phase 3 clinical trial of sodium oligomannate for mild-to-moderate Alzheimer's dementia. Alzheimer's Res. Ther. 2021, 13, 1-11. [CrossRef]

156. Vonhoff, F.; Keshishian, H. Activity-Dependent Synaptic Refinement: New Insights from Drosophila. Front. Syst. Neurosci. 2017, 11, 23. [CrossRef]

157. Westfall, S.; Lomis, N.; Kahouli, I.; Dia, S.Y.; Singh, S.P.; Prakash, S. Microbiome, probiotics and neurodegenerative diseases: Deciphering the gut brain axis. Cell. Mol. Life Sci. 2017, 74, 3769-3787. [CrossRef] [PubMed]

158. Westfall, S.; Lomis, N.; Prakash, S. A novel synbiotic delays Alzheimer's disease onset via combinatorial gut-brain-axis signaling in Drosophila melanogaster. PLoS ONE 2019, 14, e0214985. [CrossRef]

159. Bonfili, L.; Cecarini, V.; Gogoi, O.; Berardi, S.; Scarpona, S.; Angeletti, M.; Rossi, G.; Eleuteri, A.M. Gut microbiota manipulation through probiotics oral administration restores glucose homeostasis in a mouse model of Alzheimer's disease. Neurobiol. Aging 2020, 87, 35-43. [CrossRef]

160. Nagpal, R.; Neth, B.J.; Wang, S.; Craft, S.; Yadav, H. Modified Mediterranean-ketogenic diet modulates gut microbiome and short-chain fatty acids in association with Alzheimer's disease markers in subjects with mild cognitive impairment. EBioMedicine 2019, 47, 529-542. [CrossRef]

161. Rosenthal, S.L.; Kamboh, M.I. Late-Onset Alzheimer's Disease Genes and the Potentially Implicated Pathways. Curr. Genet. Med. Rep. 2014, 2, 85-101. [CrossRef] [PubMed]

162. Shukla, S.; Tekwani, B.L. Histone Deacetylases Inhibitors in Neurodegenerative Diseases, Neuroprotection and Neuronal Differentiation. Front. Pharmacol. 2020, 11, 537. [CrossRef]

163. Lee, S.-H.; Gomes, S.M.; Ghalayini, J.; Iliadi, K.G.; Boulianne, G.L. Angiotensin Converting Enzyme Inhibitors and Angiotensin Receptor Blockers Rescue Memory Defects in Drosophila-Expressing Alzheimer's Disease-Related Transgenes Independently of the Canonical Renin Angiotensin System. eNeuro 2020, 7. [CrossRef]

164. Gabrawy, M.M.; Campbell, S.; Carbone, M.A.; Morozova, T.V.; Arya, G.H.; Turlapati, L.B.; Walston, J.D.; Starz-Gaiano, M.; Everett, L.; Mackay, T.F.C.; et al. Lisinopril Preserves Physical Resilience and Extends Life Span in a Genotype-Specific Manner in Drosophila melanogaster. J. Gerontol. Ser. A Boil. Sci. Med Sci. 2019, 74, 1844-1852. [CrossRef] 
165. Ederer, K.A.; Jin, K.; Bouslog, S.; Wang, L.; Gorman, G.S.; Rowe, G.C.; Abadir, P.; Raftery, D.; Moellering, D.; Promislow, D.; et al. Age- and Genotype-Specific Effects of the Angiotensin-Converting Enzyme Inhibitor Lisinopril on Mitochondrial and Metabolic Parameters in Drosophila melanogaster. Int. J. Mol. Sci. 2018, 19, 3351. [CrossRef]

166. Ancidoni, A.; Bacigalupo, I.; Remoli, G.; Lacorte, E.; Piscopo, P.; Sarti, G.; Corbo, M.; Vanacore, N.; Canevelli, M. Anticancer drugs repurposed for Alzheimer's disease: A systematic review. Alzheimer's Res. Ther. 2021, 13, 1-15. [CrossRef]

167. Ozlu, C.; Bailey, R.M.; Sinnett, S.; Goodspeed, K.D. Gene Transfer Therapy for Neurodevelopmental Disorders. Dev. Neurosci. 2021, 1-11. [CrossRef]

168. Khan, I.; Preeti, K.; Fernandes, V.; Khatri, D.K.; Singh, S.B. Role of MicroRNAs, Aptamers in Neuroinflammation and Neurodegenerative Disorders. Cell. Mol. Neurobiol. 2021, 1-21. [CrossRef]

169. Barman, N.C.; Khan, N.M.; Islam, M.; Nain, Z.; Roy, R.K.; Haque, A.; Barman, S.K. CRISPR-Cas9: A Promising Genome Editing Therapeutic Tool for Alzheimer's Disease-A Narrative Review. Neurol. Ther. 2020, 9, 419-434. [CrossRef] [PubMed]

170. Douglas, A.E. Drosophila and its gut microbes: A model for drug-microbiome interactions. Drug Discov. Today Dis. Model. 2018, 28, 43-49. [CrossRef]

171. Ludington, W.B.; Ja, W.W. Drosophila as a model for the gut microbiome. PLoS Pathog. 2020, 16, e1008398. [CrossRef] [PubMed]

172. Bothwell, M.; Giniger, E. Alzheimer's Disease: Neurodevelopment Converges with Neurodegeneration. Cell 2000, 102, 271-273. [CrossRef]

173. Karisetty, B.C.; Bhatnagar, A.; Armour, E.M.; Beaver, M.; Zhang, H.; Elefant, F. Amyloid- $\beta$ Peptide Impact on Synaptic Function and Neuroepigenetic Gene Control Reveal New Therapeutic Strategies for Alzheimer's Disease. Front. Mol. Neurosci. 2020, 13. [CrossRef] [PubMed]

174. Esposito, M.; Sherr, G.L. Epigenetic Modifications in Alzheimer's Neuropathology and Therapeutics. Front. Neurosci. 2019, 13, 476. [CrossRef] [PubMed] 